\title{
Luxury Brands Market in India: Recent Trends Challenges and Opportunities
}

\author{
Sukhvinder Singh ${ }^{1}$ and Vandana Gupta ${ }^{2}$ \\ ${ }^{1 \& 2}$ Assistant Professor, Amity School of Business, Amity University, Noida, Uttar Pradesh, India \\ E-Mail: ssingh53@amity.edu
}

\begin{abstract}
Luxury Brands industry has undergone series of dynamic changes in last 20 years. India's luxury market is set to grow USD 30 billion from USD 23.8 billion by the end of year 2020 attributing to growing influx and expose to international brands, high purchase power of Indian upper class consumer in tier II and tier III cities. According to study by Assocham, Indian Luxury market is expected to expand five folds in next three years and the number of millionaire expected to multiply three times. India, has rich fashion history of bright colours, exotic saris, elegant embroidery, and stunning jewellery, that has been an inspiration for designers around the world. Hence, many international luxury brands recognize the potential of the market of Indian owing to the growing number of billionaires and the rise of the urban elite class. The industry has faced challenges from technological advancements, high import duties and counterfeits products. The purpose of this research paper is to highlight the main areas of concern for the future of luxurybrand industry in Indian market with its challenges, trends and opportunities.

Keywords: Luxury, BRICS Ultra High Net Worth Individuals, Counterfeits, Millennial
\end{abstract}

\section{INTRODUCTION}

India has rich tradition of luxury. It was addressed a Golden Bird. India's love with luxury goes far back in history, to pre-independence era with its many Rajas and Maharajas who have redefined taste and were connoisseurs of luxury. Eminent brands like Cartier, Rolls Royce, Chaumet etc. not just found inspiration in India but also counted the country's elite as their biggest client. Necklace commissioned for Maharaja Bhupinder Singh of Patiala was Cartier's biggest single commission execution. For luxury car maker Rolls Royce, India was its biggest client. Of the total 3,600 cars sold by them between 1907 and 1947, India accounted for more than 1,000. However, in the later times, all these big players have but disappeared from the Indian market. India has one section of the society that is super rich which can afford the most expensive brands and yet another section lives below poverty line. High taxes and general conservative behavior of people after independence discouraged them from flamboyance spending and display of wealth. Positive economic reforms and young, open minded, tech savvy population in India opens plethora of opportunities for luxury brands in India.

\section{A. Global Scenario}

India's economy is much stronger now. The indicators are all favorable. The fiscal deficit, inflation index, current account deficit and the foreign exchange reserves are all healthier and growth-driven. The percentage annual growth rates projections in India stand best in the BRICS region at 7.5 percent in India as against 6.3 percent in China, 2.1 percent in South Africa and almost negligible in Brazil and Russia. India, alone, is expected to emerge as the world's fastest-growing major economy. So is there an India opportunity for luxury brands

\section{REVIEW OF LITERATURE}

The Oxford Dictionary has defined Luxury as, "A state of great comfort or elegance, especially when involving great expense". Defining luxury has been always been very subjective. Scholars explain it dynamically with changing times and scenarios. Luxury is any expenditure that goes beyond the necessary, as Werner Sombart begins his essay on the concept and nature of luxury (Sombart, 1992). While the notion that luxury is essentially surplus is a common one, it has been contested in scholarly debates. In the literature, "luxury" has frequently been used to define the top category of prestigious brands (Vigneron and Johnson, 2004).

Nueno and Quelch (1998) defined luxury brands as "those whose ratio of functional utility to price is low while the ratio of intangible and situational utility to price is high". Luxury brands can be defined as highquality, scarce, high-priced or rare brands (Kapferer, 1998). Dubois and Paternault (1995) remarked that "luxury items are bought for what they mean, beyond what they are". Research has highlighted that luxury goods score higher in experiential and symbolic dimensions, whereas non-luxury goods score higher in the functional dimension. They help to satisfy the sociopsychological needs of people (Shukla et al., 2009). Individuals strive to create positive social images by purchasing luxury goods (Hume, 2010; Shukla, 2010). Luxury fashion goods consist of apparel, accessories, handbags, shoes, watches, jewelry and perfume for which the mere use of a particular, branded product brings prestige to its owners, apart from any functional utility (Vigneron and Johnson, 2004). Various brands like Hermès, Chanel and Louis Vuitton share important characteristics of luxury such as exorbitant prices, outstanding quality, aesthetic designs, heritage value, 
brand images, rareness and true reflections of personality (Dubois and Duquesne, 1993; Nueno and Quelch, 1998).

Articles in Luxury Retail Management like How the World's Top Brands Provide Quality Product and Service Support by Michel Chevalier, Michel Gutsatz (2012), Luxury Strategy in Action by Jonas Hoffmann, Ivan CosteManiere (2011), Jean-Noel Kapferer, Vincent Bastien (2009) in the book - The luxury strategy: break the rules of marketing to build luxury brands $\|$ highlights that luxury is in fashion. The Luxury Strategy unveils that any market, including $\mathrm{B}$ to $\mathrm{B}$, a company can learn from luxury strategies to differentiate itself profitably. An important book authored by Robin Lent, Genevieve Tour (2009) titled -Selling Luxury: Connect with Affluent Customers, Create Unique Experiences through Impeccable Service, and Close the Salell. Michael Boroian, Alix de Poix (2009) in their book - India by Design: The Pursuit of Luxury and Fashion\| intend to say that a rational view of the growing Global Luxury and Fashion Brands market in India. Scholars like Michel Chevalier, Gerald Mazzalovo (2008), UcheOkonkwo (2007), Pamela Danziger (2005) gave luxury marketing and strategies that marketers can implement to build their luxury brands

\section{OPPORTUNITIES}

\section{A. Positive Economic Reforms}

In India the luxury goods sector is still in the early stages of development, with a slow but constant growth and presenting many opportunities for investing companies. Demand for luxury goods is expected to remain strong over the next year, although there will be challenges, one of which is to gain the government's support. Also problematic are the high import duties on luxury goods, which constitute a barrier to price parity with other countries. Further, demonetization and the introduction of GST dampened the luxury goods segment. The positive economic prospects for the country seem sufficient for a rise in aspirations among urban consumers with higher disposable income to invest in luxury products.

\section{B. Rise in Number of Ultra High Net Worth Individuals}

India's super rich and affluent class currently is only 4 percent of the overall population, expected to grow from 10 million in 2016 to 26 million by 2026 . According to recent report by Kotak Wealth Management, in India, households earning upwards of Rs 250mn were about 146,600 in 2016 (with combined net worth of Rs $135 \mathrm{tn}$ ). These were up by $7 \%$ from 137,100 (with combined net worth of Rs 128tn) in 2015. However over the past 5 years, the increase in the number of households has been very steep at $16 \%$ Compounded Annual Growth Rate (CAGR) from 81,000 in 2011-12. These are expected to increase substantially to about 294,000 by 2021, holding a total net worth of Rs 319 tn.

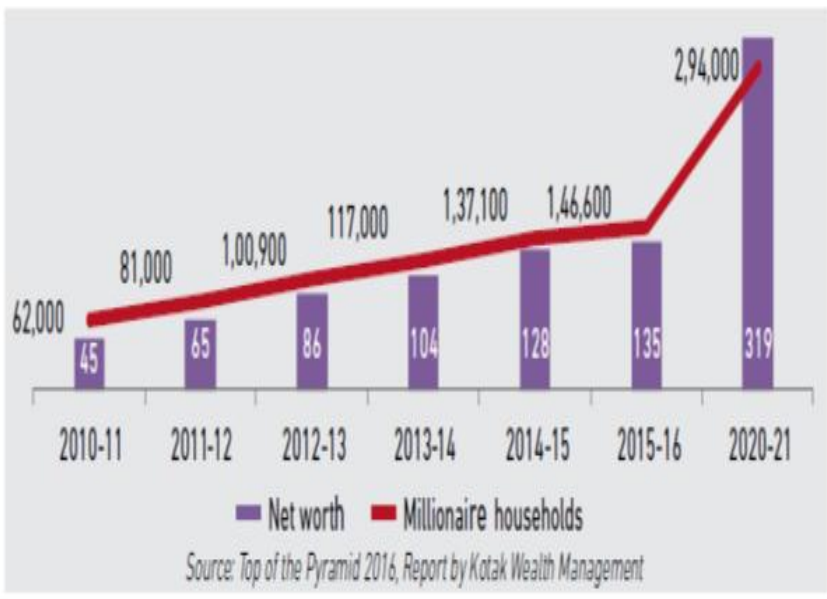

Fig. 1 Showing Net Worth and Miillionaire Household in India

Demand for luxury goods is expected to grow in congruence with increasing HNIs' and their wealth. Being a savings nation, personal and business investments are priority for the UNHIs over other expenditure, accounting for $45 \%$ of total income. Of the expenses, personal and family centered expenditures like holidays, apparel, jewelry, events and home décor etc. have traditionally been the most favored buys and are expected to continue to be the topmost category, contributing to $68 \%$ of their total spends. Steady economic growth coupled with increased disposable income and a strong government will help provide an impetus for the rising optimism and growth in this sector.

\section{Increasing Awareness and Changing Mind Sets}

The millennial generation of the India is globe trotters and highly tech savvy. Hence, they are more aware as they are exposed to on-goings of the world. Today's generation is open to spending and experimenting with different brands and styles that the earlier generation would have refrained. They expect newer styles than before and relatively exclusive product.

\section{Young Vibrant Population}

Over $72 \%$ of India's population is younger than 30 years. This trend is expected to continue for a foreseeable future. In 2020, India's median age will be about 29 years, while the working age population (15-64 years) will cross 1 bn by 2050. Most of these millennials belong to the Double Income no Kids (DINK) and the High Income Not Rich Yet (HENRY) category. These categories represent the upwardly mobile population or the aspirants desiring a good lifestyle. This is expected to increase their disposable income and thus their spending capacity, representing a huge potential in India.

\section{E. Urbanization and Growing Middle Class}

Increase in wealth of Tier-II and III cities has given rise to new middle class and HNIs in these cities. As per the report by Kotak Wealth Management, about $40 \%$ of India's 
UHNIs are concentrated in the Tier II and III cities. The post 1991 liberalization era, helped the rise of neo middle class. This has been the highest growing market, with high discretionary spending. It is estimated that Indian cites will be a home to about $40 \%$ of the population, accounting for $60 \%$ of total consumption by 2025 (Okonkwo, U. 2007)

\section{RECENT TRENDS IN INDIAN LUXURY INDUSTRY}

\section{A. Women Driving Luxury Segment}

A recent survey conducted by ASSOCHAM, targeting about 500 women earning in the range of Rs 5-10lac per year found some interesting results. The Indian women luxury market is estimated to be around $\$ 9 \mathrm{bn}$, with an overall share of $15 \%$. The country currently boasts of over 1,200 highly affluent women with a combined net-worth of over \$100bn. Increasing female workforce and their high incomes spread across metros and non metros have contributed to this unprecedented rise. Apparels and accessories like jewelry and watches, personal care products and electronics are the most favored items of purchased by the women.

\section{B. Online Availability of Luxury Products}

Internet penetration in the country is increasing, with about $350 \mathrm{mn}$ people using internet, many of them are youngsters who are eager to experiment and comfortable making online purchases. Today's youth is connected to the world and aware of its surroundings. They have increased knowledge of luxury goods and services and have sufficient disposable income to support a high lifestyle. Online partnerships by brands with shopping websites have increased brands' reach resulting in engaging more people (Low, G.S. and Lamb, C.W. 2000) Presence of these shopping portals as mobile applications have also helped the companies to reach many people in remote locations. While these brands are available online, Indian consumer still prefers to buy products, especially high value ones in physical shops.

\section{Social Media Engagement}

Many companies are actively engaging in social media analysis and use it effectively to increase their brand appeal to a broader set of consumers. In August 2015, there were approximately $28 \mathrm{mn}$ social media users. This represents a huge opportunity for the companies who engage proactively in developing appealing and innovative content to lure potential customers. Effective social media engagements can increase brand recognition and appeal, and recognized brands are more likely to be preferred by the consumers.

\section{Rise in Luxury Startups}

As a response to robust increase in demand of luxury products, many startups have mushroomed in the country catering exclusively to luxury products. One of the startups
Kidology caters exclusively to kids wear designed by wellknown designers. There are many portals that focus on refurbishing and selling used luxury products. They not just guarantee the originality of the products, but also make luxury products more reachable to a segment of population that otherwise wouldn't be able to afford it. Online shopping startups like "Luxepolis" and "Confidential couture" are some of the examples.

\section{CHALLENGES}

\section{A. Lack of Suitable Infrastructure}

In India there is lack of space and environment for luxury brands. Luxury brands showrooms are restricted to malls and hotels in India. There are few retail outlets of luxury brands in India. Indian high street markets are overcrowded and cluttered and hence do not provide the ambience for luxury brand. Therefore, weak infrastructure acts as one of the major challenge to Indian luxury retail market.

\section{B. High Import Duties}

High import duties also restrict the growth of Indian luxury market. The duties are higher as compared to other Asian countries like Singapore. Import duties range from $20 \%$ to as high as $150 \%$ which discouragers the international players to enter India as well ascustomers to buy in India. Therefore, customers prefer to fly to Dubai or Singapore wherethey get large variety at competitive prices due to no import duties unlike India.

\section{High Local Taxes}

Currently there is a plethora of taxes levied on the luxury sector. These taxes cumulatively inflate the prices upwards of $20 \%$ that a customer would pay in any other major market. This excessively inflates the ultimate price that the customer pays, thus making it a huge trade barrier for the industry. The implantation of GST which will likely be implement in April 2017 will rationalized the tax structure

\section{Shortage of Quality Workforce}

Historically, luxury in India has been limited to a very small proportion of the population, which also used to shop abroad. This restricted the general population's exposure to luxury product thus their understanding. With expansion of new luxury brands in the country, there is a lack of employable workforce who has knowledge of luxury products and skills to sell them. This is a major challenge for companies planning to set up/ expand their base in India. While many companies have their own trainingmechanisms, the issues still remain.

\section{E. Parallel Growing Market of Counterfeits}

According to the Associated Chambers of Commerce and Industry of India, the market for counterfeits luxury goods 
in India is likely to reach Rs60 billion by end of 2018 and is one of the major challenges for luxury brands. The market of counterfeits is growing owing to legal loopholes and large number of online portals selling fake products. Other issues like the following are also cause of great worry.

1. Offering import of company's seconds at heavy discount price.

2. Whatsapp group offering and circulating counterfeits products.

3. Copying design of luxury products to produce replicas (especially in apparels and jewellery).

4. Social media sites selling and distributing counterfeit products.

\section{E. Legislation}

Indian Government allows for $51 \%$ foreign direct investment (FDI) in multi-brand retail and $100 \%$ in singlebrand retail. This means that luxury brands can be directly owned controlled and operated in India. However, to protect local industry, a further clause has been added which makes it mandatory that where FDI is above $51 \%$, at least $30 \%$ of the value of products sold must be sourced from Indian small industries, as well as village and cottage industries, artisans and craftsmen. This is quite difficult for luxury brands, as it may require them not merely to change their business model, but to alter their brand DNA. Following a recent amendment, the government has eased the local sourcing rule for foreign single-brand retailers for the first five years, provided that they are already procuring goods for their global operations from India.

\section{CONCLUSION}

The Indian Luxury market today holds tremendous potential for both international and home grown luxury brands that will become globally recognized in the future. Thus, the time is ripe for the country for adoption of "Make-AnIndian-Brand" campaign, which can eventually be showcased to the world at large. Before that, the brand resilience needs to be checked in the Indian market itself. If brand is successful in garnering local acceptance, it could then launched in other countries as well. Brands like Forest essential and Kama Ayurveda, have followed this path and now have generated a global following. Ambitious plans like these require robust, readily available and affordable infrastructure. Indian companies and property developers could imitate European markets, where Luxury villages have been created on the outskirts of major towns, offering luxury products at affordable prices. Initiatives like these could find high appeal to the value conscious Indians who have yet to develop a taste for premium and luxury goods.

\section{REFERENCES}

[1] Assocham (2016).The rise of online shopping for luxury brands in India. Retrieved from http://indianexpress.com/ article/technology/ sponsored/the-rise-of-online-shopping-for-luxurybrands-in-india/

[2] Dubois, B., \& Laurent, G. (1993). Attitudes towards the concept of luxury: an exploratory analysis. Asia Pacific Advances in Consumer Research, 1(2), 273-278.

[3] Dubois, B.., \& Paternault, C. (1995). Observations: understanding the world of international luxury brands. Journal of Advertising Research, 35(4), 69-76.

[4] Kapferer, J. (1998). Why are we seduced by luxury brands? Journal of Brand Management, 6(1), 44-49.

[5] King, J. (2016). Chanel trumps Louis Vuitton, receiving highest mentions on social: NetBase. Retrieved from https://www.luxury daily.com/luxury-gathers-to-discuss-innovation-tradition-atfacc symposium/

[6] Low, G.S., \& Lamb, C.W. (2000). The measurement and dimensionality of brand associations. Journal of Product \& Brand Management, 9(6), 350-370

[7] Nueno, J.L., \& Quelch, J.A. (1998). The mass marketing of luxury. Business Horizons, 41(6), 61-69.

[8] Okonkwo, U. (2007). Luxury Fashion Branding: Trends, Tactics, Techniques, Palgrave Macmillan, New York, NY.

[9] Shukla, P. (2011). Impact of interpersonal influences, brand origin and brand image on luxury purchase intentions: Measuring interfunctional interactions and a cross-national comparison. Journal of World Business, 46, 242-252.

[10] Vigneron, F., \& Johnson, L.W. (2004).Measuring perception of brand luxury.Journal of Brand Management, 11(6), 484-506. 